\title{
Management Strategies of Professional Zakat Funds for Mustahiq Family Welfare By Amil Zakat Body
}

\author{
Muhammad Iqbal $^{1 *}$, Rusli Rusli ${ }^{2}$, and Musyahidah Musyahidah ${ }^{3}$ \\ ${ }^{1}$ Islamic Law Department, Postgraduate, Institut Agama Islam Negeri Palu \\ ${ }^{2}$ Islamic Law Department, Postgraduate, Institut Agama Islam Negeri Palu \\ ${ }^{3}$ Islamic Economics Department, Faculty of Islamic Economics and Business, Institut Agama Islam Negeri Palu
}

\section{ABSTRACT}

This research deals with professional zakat fund management strategy for mustahiqfamily welfare by Zakat Amil Body of Palu City BadanAmil Zakat. This research is qualitative research that tried to reveal and interpret this developing phenomenon. This is case study that used such data collectiontechniques such as observation, interview, and documentation, while data analysis includes data reduction, presentation and verification which ends with checking the validity of the data with the source triangulation method.

The result showed that zakat collection units receive all kinds of charity such as infaq, sadaqah, as well as profession zakat that muzakkiwill to pay. Second is direct acceptance; that is, a zakat payer comes directly to the Baznas Office to hand over zakat, infaqand sadaqah (ZIS) to the officers in Baznas. The distribution is carried out in two ways: first, mustahiqsare given what they need in terms of daily basic necessities; secondly, aid is given to mustahiqs who have business to help them develop their business.
ARTICLE

INFORMATION

Keywords:

Zakat of profession, Management, Mustahiq,

Badan Amil Zakat 


\section{INTRODUCTION}

Zakat is not just temporary assistance for the poor who after being left back to poverty, but zakat is also a permanent and organized aid. Every year, good will come to the recipients of zakat due to hawl (zakat payment deadline), such as animal zakat, cash, trade and industry. Likewise, when harvest comes, another kindness also comes, such as zakat from plantations in the form of fruits and other staples.

Since 4 centuries ago, zakat is one of the instruments considered able to overcome the economic crisis and support the economic development of society. In its implementation, zakat plays a role in eliminating the poverty.

In addition, zakat can increase the economic and social growth of the community. Theoretically, the allocation of zakat to small communities will increase people's income and consumption. This will not only have an impact on increasing production and investment, but demand for labor will also increase. Thus, unemployment as an outbreak of social crisis can be overcome.

On the one hand, zakat will create a spirit of assistance ( $\mathrm{t} a^{\prime}$ 'awun). On the other hand, well-paid zakat will improve the quality of faith, cleanse and purify the soul, develop and bless possessions. Zakat that is well managed and trustworthy will be able to create prosperity for the Islamic community, improve work ethic and also serves as an institution of economic equality.

The concept of Islam in the distribution of zakat is by delivering zakat rights to those who need it. Because, the basic and operational basis of zakat is the direct distribution after the collection of zakat funds. Distribution must be in accordance with the needs and benefits set out in sharia, which in turn will have an impact on increasing the amount of zakat received by the Zakat Amil Body (BAZ).

The Islamic community in Palu is the largest. Of course, the potential for zakat is also large. However, the amount of zakat received is not significant. The decrease in zakat receipts has an impact on the empowerment of the people and the alleviation of the poor in Palu. Meanwhile, the poor in Palu in 2016 amounted to 26.24 thousand or $7.06 \%$ of the population. So that poverty alleviation and community empowerment in Palu through the distribution of zakat by Baznas of Palu is still far from expectations, because it is not directly proportional to the amount of the zakat payers (muzakki) with zakat received. 
The receipt of professional zakat by the Baznas of Palu is still considered new, but the implementation of the professional zakat reception has actually been carried out from the past few years. This can be seen in the Annual Report of Baznas in Palu in the last 2 years by combining the receipt of zakat mal with professional zakat.

Although professional zakat is still newly "managed", but actually this professional zakat is a very potential instrument to increase the receipt of zakat. However, the reality is still far below the amount of charity (infaq and shadaqah) received by BAZ of Palu City.

This can be seen in the Collection and Distribution Report from BAZNAS in 2016 where the Zakat Mal and Professional Zakat that were collected reached Rp. $5,293,000$. This amount is still lacking when compared to the number of professional workers both in Government Agencies and in the private sector in Palu. ${ }^{1}$

One of the reasons for the lack of receiving professional zakat is lack of socialization carried out by Baznas of Palu City Baznas on professional zakat to the public, so that the public is less informed about it. Due to the lack of dissemination of information to the public, this makes the

\footnotetext{
${ }^{1}$ Baznas Kota Palu "Report on collection, distribution and utilization of the zakat, infaqand sadaqah" byBaznas Kota Palu, Annual Report 2016, 17 February 2017.
}

receipt of professional zakat inBaznas ofPalu City become less. For this reason, it is necessary to socialize sufficient information regarding the importance of professional zakat obligations and calculations so that they can stimulate and facilitate muzakkiwho want to give their profession zakat. This is important because professional zakat is one type of zakat which is very potential to be applied because it can boost the receipt of zakat, given the large number of professional workers from both the public and private sectors scattered throughout Palu City.

Meanwhile, the existing professional zakat is only collected from people who already know and understand the professional zakat obligation from various media about the existence of zakat that is imposed on the income received, so that from that information then muzakki can spend his zakat toBaznas ofPalu City, and even then it is still limited only to certain people who have a high enough level of awareness of the obligation to issue zakat on the income received so far.

Therefore, it is a challenge for Baznas of Palu City in the future how to explore and maximize the receipt of professional zakat, especially those frommuzakkis who work in Government and private sector so that they can contribute in order to boost zakat receipts. 
When the potential of professional zakat that exists in the community can be explored properly, this becomes a large capital to help and empower people in need. This is the commitment of Baznas ofPalu City together with the local government to alleviate poverty through zakat empowerment.

So what needs to be done by the Baznas of Palu City is how the collected professional zakat can be distributed and utilized properly by the community. This is because the collection and utilization of zakat are two things that are equally important. The collection is maximum, and distribution or utilization run effectively and on target.

\section{LITERATURE REVIEW}

\subsection{Previous Research}

Abdul Karim Assalawi in his thesis, entitled Zakat ProfesiDalamPerspektifHukumdanEtik(Prof essional Zakat in Legal and Ethical Perspectives) said that professional zakat if made analogy with plant and fruit zakat is $5 \%$ and $10 \%$, respectively. But if it is made analogy with gold and trade zakat, then the zakat is $2.5 \%$. If you want to pay more, it is better. Abdul Karim Assalawi did not explain which percentage is the right benchmark in paying professional zakat. ${ }^{2}$ Another study was conducted by Muhammad Hadi, entitled Problematika Zakat Dan SolusinyaSebuahTinjauanSosiologiHukum Islam (The Problems of Zakat and Its Solution A Sociology of Islamic Law Review). In his thesis, Hadi concluded that the views of the professional zakat obligations among civil servants seemed diverse. Civil servants make payment of charity or alms in the form infaqand zakat to the Zakat Collecting Unit (Unit Pengumpul Zakat) and the Zakat Amil Body (BadanAmil Zakat) based on the understanding of zakat obligations, Regent's Decree and interpretations of scholars in the positive legal framework. ${ }^{3}$

This research is different from researchs that have been done by previous researchers. Although in the same field, professional zakat in this research is the application of the concept of professional zakat which focuses more on the strategy of managing and utilizing zakat funds as well as their utilization for the welfare of the mustahiq family through the Amil Zakat Board in the city of Palu so that they can be

\footnotetext{
${ }^{2}$ Abdul Karim Assalawi, Zakat ProfesiDalamPerspektifHukum Dan Etik, (Thesis, IAINWalisongo, 2001), 134-135.

${ }^{3}$ Muhammad Hadi, Probelematika Zakat ProfesidanSolusinyaSebuahTinjauanHukum Islam, (Yogyakarta:pustakaPelajar, 2010), 243-244.
} 
distributed to the groups entitled to receive them.

\subsection{Professional Zakat}

Zakat is part of the property with certain conditions, which Allah Almighty obliges the owner, to be submitted to the party entitled to receive it, with certain conditions as well. Meanwhile, profession is a job that requires training and mastery of certain knowledge. Or, the profession is often interpreted as a job that requires special training and expertise.

So, professional zakat is known as zakahrawatib al-muwazhaffin (zakat of employee salary) or zakatukas al-amal almihan al hurrah (zakat on work income and private profession). Meanwhile, according to the term, professional zakat is zakat issued on each job or certain professional expertise, whether done alone or with other people/institutions, which brings in income that meets nisab (minimum limit). ${ }^{4}$ So, professional zakat is defined as zakat that is imposed on each job that generates money that meets the terms of the Nisab.

\subsection{The Category of Professional Zakat}

Professional income is the fruit of the work draining the brain and sweat done by everyone. Examples of professional income are; salaries, wages, incentives, or other names that are suited to the type of profession whether it is a job that relies on the brain or the physical abilities of its expertise and even both.

Professional zakat is zakat issued from halal business results which can bring in relatively large amounts of money easily, through a certain expertise. ${ }^{5}$ Jobs that make money are of two kinds namely:

1. Work that is carried out alone without depending on others, thanks to dexterity of the hands and brain. Income obtained in this way is professional income, such as the income of a doctor, engineer, advocate, and so forth.

2. Work done by someone for other parties, such as the government, companies, or individuals, ini which he/she earns income such as salary, wages, or honorarium. ${ }^{6}$

In another sense, professional zakat is zakat that is imposed on any work or certain professional expertise, whether done alone or together with other people or institutions,

\footnotetext{
${ }^{4}$ Yakhsyallah "Zakat ProfesiMenurutPandangan Para Ulama" Mi'raj Islamic News Agency(Kantor Berita Islam Mina). http:/mirajnews.com (14/06/2017).
}

${ }^{5}$ Hadi, Pronlematika Zakat, 58.

${ }^{6}$ Qardhawi, Fiqhuz, 459. 
which bring in income (money) that meets nisab (minimum limit for zakat). ${ }^{7}$

The results of the profession in the form of assets can be categorized into alms wealth or savings. Thus, the results of a person's profession if it meets the mandatory provisions of zakat, he is obliged to perform zakat. ${ }^{8}$ Yusuf Qardhawisaid that:

Among the things that are very important to get the attention of Muslims today is the income that is gained from their expertise, that is carried out individually or together. ${ }^{9}$

The work or profession that is carried out individually such as medical doctor, architect, legal expert, tailor, painter and others, while those carried out together such as employees using the salary system.

Wahbah al-Zuhaili specifically stated that the income received by people through their own business such as doctor, engineer, legal expert, tailor and so on, and also related to the public or private sectors such as employees who get salaries or wages in a relatively fixed time, is called in Islamic law term as al-mal al-mustafad. This is in accordance with the fatwa of ulama in Kuwait 29 Rajab 1404 H (30 April 1984). ${ }^{10}$

\footnotetext{
${ }^{7}$ DidinHafidhuddin, AndaBertanyaTentang Zakat, Infaq Dan Sedekah Kami Menjawab, (Jakarta:BAZNAS, 2004), 149.

${ }^{8}$ Al-FurqanHasbi, 125 masalah zakat, (Solo: TigaSerangkai, 2008), 217.

${ }^{9}$ Qardhawi, Fiqhuz, 487.

${ }^{10}$ Quoted inHafidhuddin, Zakat,93-94.
}

The scope of professional zakat is all the income generated by a person which is usually in the form of salary, wages, honorarium, and other similar names as long as the income does not constitute a return on assets, investments or capital.

Income generated from certain professional work (doctor, lawyer) falls within the scope of this zakat as long as the element of work has the most fundamental role in generating such income.

2.5 Utilization of Professional Zakat for Community Welfare

In relation to the utilization of zakat, it is necessary to consider the target of zakat distribution in various sectors of life, including among others:

a. Economic sector, such as community income is relatively low due to lack of venture capital, less of capability in the field of agricultural cultivation and weak performance in the field of agribusiness;

b. Religious sector that includes religious educational institution and community that are concerned with religion such as people who are unable to pay debts, mosque imams, preachers, madrasa teachers, syara officers, and others who receive less attention from the community;

c. Social sector, such aslack of public service facilities and facilities (polyclinic, 
venture capital, economic union or small farmers and so on);

d. Office sector, such as certain groups that must be empowered, and which need special handling (disaster, illness with the burden of debt);

e. Enterprise sector, such as education, houses of worship, community economic empowerment in the form of agricultural businesses and social services. ${ }^{11}$

With the utilization or distribution of zakat properly, community's understanding that is static will change to a dynamic understanding, and this in turn will get enough attention from the Islamic Ummah.

\section{METHOD OF RESEARCH}

This study used qualitative research methods. Qualitative research is a descriptive with a social religious approach. Qualitative method is a type of research that uses descriptive data, in the form of written or spoken words from observable people or behavior. $^{12}$

Qualitative research emphasizes the depth of data obtained by researchers. The deeper and detailed the data obtained, the better the quality of the research. So as to achieve these results, the researcher

\footnotetext{
11 (Hasibuan , 2017)

12 Robert C. \&Stren J. Tailor,
} KualitatifDasar-DasarPenelitian (Usaha Nasional, 1993),5. participates in the event that is being studied. In this study, researchers examined the management of professional zakat funds by the National Amil Zakat Body and analyzed its use for mustahiq family welfare in Palu.

Data were collected using observation techniques, in-depth interviews and studies from shared written documents. Meanwhile, the data analysis is done using reduction and verification techniques with various data sources. The reduced data is then analyzed by claiming to the theoretical concepts used in this study.

\section{RESULTS AND DISCUSSION}

4.1 Professional Zakat Fund Management Strategies

Basically, the management of the Palu'sAmil Zakat Board is not different from that in previous years, although the management aspect has used the term commissioner, which is a collective management where one chair is assisted by four deputies who have their respective duties and responsibilities. The elected chair and vice are the result of selection from an independent team. This process was carried out at the first time in the history of the recruitment of Baznasadminstrators in Palu.

At the MochsenAlydrus' leadership, BAZ Palu is still limited to coordination and consolidation, as well as establishing Zakat 
Collecting Units, abbreviated as UPZ in every agency, Office of Religious Affairs, State-owned Enterprises, Regional owned Enterprises, and private companies in the Palu City Government. This is based on the Formal Letter of the Mayor of Palu No. 450.12/1566/Kesraon September 3, 2001, that UPZ has the duty as an extension of the Regional BAZ in carrying out the function of fundraising in various agencies and institutions. $^{13}$

In the following period, the Baznas of Palu City was chaired by KasimYahya.The first step that he took in managing this agency is to coordinate with the Regional Government, in this case the Mayor of Palu in order to carry out socialization to the Regional Work Units, abbreviated as SKPD under the working area of Local Government.

The Baznas of Palu City considers that the civil servants in the Palu Government are made potentially as zakat payers (muzakki) in organizing zakat, infaq and shadaqah funds in the Palu area. So that the target of the implementation of this socialization is the Muslim civil servants in government agencies and schools. This was stated by Kalsum P. Angku that

\footnotetext{
${ }^{13}$ Interview with KalsumAngku, administrative staff of BaznasPalu (15 August 2017).
}

During KasimYahya's leadership, we carry out coordination with the Palu City Government in order to carry out socialization to the level of SKPD in the City of Palu; so through this socialization we can urge the public especially employees to issue zakat, infaq and shadaqah as well as introduce the task of Baznas of Palu City in distributing zakat, infaq and alms issued by Employees. ${ }^{14}$

In addition to the socialization to work units, the socialization was carried out in various non-formal meetings including Friday sermons, Islamic studies circles, and others. All media can be used to socialize Baznas as a legitimate institution formed by the government that functions to receive, manage and distribute Zakat, Infaq and Sadaqah (ZIS), as well as making people aware of purifying their assets and income from frauds by issuing zakat of assets or professions.

From this socialization, the Palu Mayor's Instruction No. 01 of 2002 was signed by BasoLamakarate on 31 October 2002 regarding the collection of Zakat, Infaq and Sadaqah (ZIS) addressed to all Muslimcivil servants within the City Government of Palu to issue Zakat, Infaq and Sadaqah (ZIS) each month.

$\begin{array}{llr}\text { Zakat } & \text { InfaqShadaqah } & \text { (ZIS) } \\ \text { fundraising collected through } & \text { Zakat } \\ \text { Collecting-Unit scattered in various agencies }\end{array}$

${ }^{14}$ Interview with

KalsumAngku,administrative staff of BaznasPalu(15 August 2017). 
or offices and schools is still actively running until now carried out by the Baznas of Palu City. HalimatusSa'diyah, one of the staff at Palu City Baznas explained:

The collection of zakat, infaq and shadaqah funds through Zakat Collecting-Unit in offices under the City Government of Palu is still running until now, every month the ZIS funds are collected and then deposited to the Treasurer or transferred directly to the Baznas Treasurer account in Palu City. ${ }^{15}$

Funds collected through UPZ are still limited to infaq and shadaqah that are deposited by the state civil apparatus based on their class. Although the collection is based on the Mayor's Instruction, but there are still employees in an agency or institution who did not do their obligation to issueinfaq and shadaqah every month. In fact, there are still many offices that have not yet implemented the Mayor's instructions.

This shows that there is still a lack of awareness of the state civil apparatus to clean up the income they receive through infaq and shadaqah collected by UPZ in their agencies/offices where they work. This is a challenge that must be resolved by the Palu City Baznas commissioners to take strategic steps in order to increase public awareness for tithe, infaq and shadaqah.

\footnotetext{
${ }^{15}$ Interview with HalimatusSa'diyah, administrativestaff of BaznasPaluon 08 August 2017.
}

In addition to infaq and shadaqah, there is also revenue from the zakat sector, especially zakat of profession, both through UPZ channels in government and private agencies or directly through the Palu City Baznas Office, as conducted by Anutapura Hospital, as one of the institutions under the control of the Regional Government, distributing zakat of its profession through the UPZ channels such as doctors practicing at the hospital. They issued their profession zakat directly to UPZ. As KalsumAngku said:

In addition to infaq and shadaqah received by the Palu City Baznas there is also acceptance from zakat sector including professional zakat through the UPZ channels in government and private agencies, or directly go the office ofPalu City Baznas. ${ }^{16}$

4.2 Utilization of Professional Zakat for the Welfare of MustahiqFamily

Zakat which has been collected and managed by the Zakat Amil Body must be distributed to those entitled to receive zakat for their welfare. One of the functions and objectives of zakat is to reduce the gap between the poor and the rich.With the existence of zakat, people's welfare can be achieved. This is the target to be achieved by the Baznas of Palu City as one of its visions: Maximizing the role of zakat in reducing

$\begin{array}{cc}{ }^{16} \text { Interview } & \text { with }\end{array}$ KalsumAngku,


poverty and unemployment through education, health, productive economics and socio-religious fields based on community empowerment approaches.

The distribution of zakat is one of the most important aspects in the process of zakat management. Therefore,Baznas ofPalu City must have the accuracy of distributing zakat to the people who need it, because there are people who do not want to show their inability, and some are deliberately show their poverty with begging way. So it is feared that there are those who accept and those who are not, even though both mustahiq are entitled to be empowered. Therefore, cooperation is needed between the Baznas of Palu City with various parties both from the elementsof society, religious leaders and the government to work together, interact with each other to provide accurate information on the existence of mustahiq. Allah has already set eight groups who are entitled to get zakat as mentioned in the Quran suraal-Taubah verse 60.

These eight group who became the the target of Baznas of Palu City for distribution of zakat, infaq and shadaqah (ZIS), so that none of them will be overlooked and forgotten so that the charity can benefit those who are entitled to get it, as the Chairman of Baznasexplained:

In terms of distribution of Zakat, Infaq and Sadaqah (ZIS) we cannot run away from the eight groups which Allah has set in the Quran surah Al-Taubah verse 60. Starting from the needy (faqir) and the poor(miskin) who do not have enough daily needs, those employed to administer it (amil), those whose hearts are attracted to the faith (mu'allafatqulubuhum), those in debt (gharimin), people who are struggling for Allah's cause ( $f i$ sabilillah) and on his way(ibnsabil). Then these eight groups who are entitled to get zakat became the Baznas concentration in Palu City to be prospered through the empowerment of zakat. ${ }^{17}$

In the case of distribution of zakat, it can be done through two ways: firstly, giving to those who are entitled to receive (mustahiq) consumptively; and secondly, providing capital or zakat aid to mustahiq, which can be developed with investment patterns. As the chairman said:

Baznas of Palu City has distributed zakat to mustahiqin two ways, namely first, zakat for consumptive purpose to mustahiq who have a desperate life, second, a productive way in whichmustahiq only needs capital for business development. However, there also people can be assisted with both ways. Besides helping them to meet their daily needs, they are also assisted with capital to develop their business in order to be independent to overcome their burden. ${ }^{18}$

From this procedure, we can see that before mustahiq receives assistance from the

\footnotetext{
${ }^{17}$ Interview with Ahmadan B. LamuriChairman of BaznasofPalu City on 02 June 2017.

${ }^{18}$ Interview with Ahmadan B. Lamuri Chairman of BaznasofPalu City on 02 June 2017.
} 
Baznas of Palu City, first a mustahiq submits a request to receive assistance. Then the proposal file is registered after the completeness is checked, then the file is collectively submitted to the Chairman of Baznas. Then the Chairmangives a note to the Deputy II of Distribution Division to validateand determine the names of field verification team. The results were submitted to the Deputy IV of Administration, Human Resources and General Affairs Division to make a Decree of the Team. After the decree was signed by the Chairman, the Deputy II facilitated the implementation of field verification by filling in the form of group of zakat recipients and program. Then the field verification team recommends the results of verification, and the results are discussed together in a meeting with the verification team, the Chairman and all deputies by determining the aid agreement, and then the Deputy III in charge of planning, financingand reporting checks the correctness of data on the allocation of aid funds to be distributed. After that the Chairman approves or rejects the request of mustahiq.Regarding the applications that are approved, Deputy IV makes a decree, where the decree is signed by the Chairman, Deputy II and Deputy III, then paid by the Treasurer. The recipient of aid brings KTP and $\mathrm{KK}$ when receiving assistance.

\section{CONCLUSION}

Based on the discussion above, it can be concluded that Baznas of Palu City in carrying out its duties and functions in relation to collection, distribution and utilization of zakat of professionimplement the zakat fundraising strategy by integrating three main factors that include:

First, internal factors such as human resources and infrastructure. It serves as a facilitator in an effort to move the wheels of the economy of the community so as to reduce the gap between the poors;Second, external factors that include mustahiqandmuzakki. Muzakki is a group of people who are capable to pay zakat, and mustahiq is a group of people who are entitled to receive zakat.

To facilitate the process of interaction between internal and external factors, it needs support of policy that is conducive both in the form of a government's regulation and agreement (MoU) with various agencies and institutions both private and public so as to create a good climate for zakat payers (muzakki) to do their obligations as a Muslim who obey God's rules, and to realize social care and deep empathy for less fortunate Muslim brothers and sisters.

\section{BIBLIOGRAPHY}


Abdul Kodir, Abdurraliman, TatananSosial Islam. Yogyakarta: PustakaPelajar, 2000.

Ahmadi,

MetodologiPenelitianKualitatif.

Ruslam,

Yogyakarta: Ar-Ruzz Media,2014.

Arikunto, Suharsini, ProsedurPenelitian; SuatuPendekatanPraktik. Jakarta: RinekaCipta, 2010.

Bakry, Hasbullah, Pedoman Islam Di Indonesia. Cet. V;jakarta: UI Press, 1988.

Bagir Al- Habsyi, Muhammad, FiqihPraktis. Bandung: Mizan, 1999.

Bungin,

MetodologiPenelitianKualitatif.

Jakarta: Rajawali, 2010.

DepartemenPendidikanNasional, KamusBaha sa Indonesia. Jakarta: PusatBahasa, 2008.

Depertemen agama, IlmuFiqhJilid I. Jakarta: DirektoratPembinaanPerguruanTinggi Agama Islam, 983.

Depertemen Agama AlqurandanTerjemahannya,. Jakarta: Alfatih: PT. INSANE MEDIA PUSTAKA, 2013.

Depdiknas, KamusBesarBahasa Indonesia. BalaiPusatpustaka, 2002.

Faisal,

MetodePenelitianPendidikan.

Surabaya:usahaNasional, 1998.

Fakhruddin, Fiqh, 143. Agar HartaBerkahdanBertambah. Cet.I; Jakarta: GemaInsani Press, 2007.

Figh Dan ManajemanZakatdi Indonesia. Malang: UIN Malang Press, 2008.

GhofurAnsori, Abdul, Hukum Dan Pemberdayaan Zakat:

UpayaSinergisWajibPajaK di Indonesia. Yogyakarta: Pilar Media.

Habsyi, Muhammad Bagir., alFiqihPraktis,. Bandung: Mizan, 1999.

Hadi, Sutrisno, Metodologi Research Jilid I.

Cet. XXIX; Yogyakarta: Andi Yogyakarta, 1997.

MetodeRiset. Yogyakarta:Andi, 2002.

Hadi, Muhammad, Pronlematika Zakat Profesi

Dan
SolusinyaSebuahTinjauanHukum

Islam. Yogyakarta: purtakapelajar, 2010.

Hamidi, MetodePenelitianKualitatif. Malang : UMM Press, 2005.

Hasbi, Al-Furqan, 125masalah zakat. Solo: TigaSerangkai, 2008.

Hasibuan, Supardi, Ahmad, MenyegarkanPemahamanTentang

Zakat, Kepala Sub

BagianPerencanaandanInformasiKeaga maan Kantor Wilayah Departemen Agama Provinsi Riau. www.kompas.com, diaksespadatanggal 18 April 2017.

Hafidhuddin, Didin, AndaBertanyaTentang Zakat, Infaq Dan Sedekah Kami Menjawab. Jakarta:BAZNAS, 2004.

Zakat DalamPerekonomian Modern, Jakarta: GeaInsani Press, 2002.

Agar HartaBerkah Dan Bertambah. Jakarta: GemaInsani, 2007.

Hasan, M. Ali., MasailFiqhiyah Ii, Zakat, Pajak, Asuransi, DanlembagaKeuangan.. Revisi.Cet.4; Jakarta: PT RajaGrafindoPersada, 2003.

Huda, Nurul, et al., Zakat PerpspektifMikroMakroPendekatanRiset, Jakarta: Prenadamedia Group, 2015.

Imam, shirudin - http:// taxman.com/? $p=17$ MenggaliPotensiPenerimaan Negara dari Zakat sebagaiSolusiPengentasanKemiskinan. Mungkinkah?Diaksespadatanggal 25Juli 2017.

Karim Assalawi, Abdul, Zakat ProfesiDalamPerspektifHukum Dan Etik, TesisPascasarjana Program StudiPemikiranHukum Islam. Semarang: PerpustakaanPascasarjana IAIN Walisongo, 2001.

Mansur, Yakhsyallah, "Zakat ProfesiMenurutPandangan Para Ulama" Mi'raj Islamic News Agency(Kantor Berita Islam Mina). http:/mirajnews.com. 
Milles, Matthew B et.al, Qualitative Data Analisys,

diterjemahkanolehTjetjepRohendiRohi didenganjudulAnalisis data Kualitatif, bukusumbertentangMetode-

metodeBaru. Cet. I; Jakarta: UI-Pres, 1992.

Mubarok, E Saefuddin, Ekonomi Islam Pengertian,Prinsip. Bogor: In Media, 2006.

Mufraini, M. Arif, Akuntansi Dan Manajemen Zakat (MengomunikasikanKesadaran Dan MembangunJaringan). Ed. I; Cet.I, Jakarta: Kencana, 2006.

Mhd. Ali, Nurdin, Zakat SebagaiInstrumenDalamKebijakanFis

kal. Ed.1; Jakarta: PT Raja GrafindoPersada, 2006.

M Echols, John, KamusInggris Indonesia. Jakarta: PT. Gramedia, 1997.

Moleong, Lexy J., MetodologiPenelitianKualitatif.

Bandung: PT. RemajaRosdaKarya, 2001.

Prastowo,

Andi, MetodePenelitianKualitatifDalamPers pektifRancanganPenelitian.

Yogyakarta: Ar-Ruzz Media, 2016.

Qardhdawi, Yusuf., al- Spektrum Zakat DalamMembangunEkonomiKerakyata n. Jakarta: Zikrul Hakim, 2005.

Qardhawi, Yusuf., al- Fiqhuz zakat. Terj. DidinHafidhuddindanHasanuddin.

Jakarta: PT. PustakaLiteraAntarnusa, 1991.

Rafi'udin\&MamanAbd. Djaliel, Prinsip Dan StrategiDakwah.

Bandung:PustakaSetia.
Rusman, $\quad$ Model- Model Pembelajaran:MengembangkanProfesi onalisme Guru. Ed. 2-Cet.5 Jakarta:RajawaliPers, 2014.

Saleh E. Hassan, KajianFiqhNabawi Dan FiqhKontemporer. Ed.I; Jakarta RajawaliPers, 2008.

Shobirin, TeknikPengelolaan Zakat Profesi ; Jurnal Zakat danWakaf. ZISWAF, Vol. 2, No. 2, Desember 2015.

Steiner, George danJhonMinner, ManajemenStrategi. Jakarta: Erlangga,2000.

Setiawan, Deny, Zakat ProfesiDalamPandangan Islam. JurnalMaret 2011.

Soemitro, RonyHanitijo, MetodePenelitianHukumdanJurimetri. Jakarta: Ghalia Indonesia, 1988.

Soekanto, Soerjono, PengantarPenelitianHukum. Jakarta : UI Press, 1986.

Susanti, DyahOchtorinadanA'anEfendi, PenelitianHukum (Legal Research). Jakarta: SinarGrafika, 2014.

Sukandarrumidi, MetodologiPenelitian, (Yogyakarta: Gajah Mada University Press, 2004.

Wahid, Achmadidkk., Islam JalanHidupku: Pendidikan Agama Islam. Jakarta: CempakaPutih, Klaten, 2005.

Yafie, Ali MenggagasFighSosial. Bandung: Mizan, 1994. 